University of Wollongong

Research Online

Faculty of Engineering and Information

Faculty of Engineering and Information

Sciences - Papers: Part A

Sciences

$1-1-2015$

Information technology and open innovation: A strategic alignment perspective

Tingru Cui

University of Wollongong, tingru@uow.edu.au

Hua Ye

University of Auckland

Hock Hai Teo

National University of Singapore

Jizhen Li

Tsinghua University

Follow this and additional works at: https://ro.uow.edu.au/eispapers

Part of the Engineering Commons, and the Science and Technology Studies Commons

Research Online is the open access institutional repository for the University of Wollongong. For further information contact the UOW Library: research-pubs@uow.edu.au 


\title{
Information technology and open innovation: A strategic alignment perspective
}

\begin{abstract}
Advances in information technology (IT) have enabled firms to increasingly rely on open innovation. Although researchers and practitioners are interested in this phenomenon, there is a lack of theoretically driven research on how IT impacts organizational open innovation performance. Drawing on the strategic IT alignment perspective and related literature, we proposed a model to explain the performance of organizational open innovation; i.e., the alignment between IT strategies and the openness of open innovation strategies results in different outcomes for open innovation. Through the analysis of data from 225 firms in China, we found that the alignment between IT flexibility and breadth enhances innovation radicalness and innovation volume, whereas the alignment between IT integration and depth positively affects innovation volume only. Innovation volume and radicalness were found to enhance organizational performance in terms of sales growth. Our study contributes to the literature on open innovation and strategic alignment. Its findings also have important managerial implications for practitioners.
\end{abstract}

\section{Keywords}

information, alignment, innovation, perspective, strategic, open, technology

Disciplines

Engineering | Science and Technology Studies

\section{Publication Details}

Cui, T., Ye, H., Teo, H. \& Li, J. (2015). Information technology and open innovation: A strategic alignment perspective. Information and Management, 52 (3), 348-358. Information and Management 


\section{Accepted Manuscript}

Title: Information Technology and Open Innovation: A

Strategic Alignment Perspective

Author: Tingru Cui Hua (Jonathan) Ye Hock Hai Teo Jizhen

$\mathrm{Li}$

PII:

S0378-7206(14)00156-6

DOI:

http://dx.doi.org/doi:10.1016/j.im.2014.12.005

Reference:

INFMAN 2779

To appear in:

INFMAN

Received date:

3-3-2014

Revised date:

3-11-2014

Accepted date:

$12-12-2014$

Please cite this article as: T. Cui, H.J. Ye, H.H. Teo, J. Li, Information Technology and Open Innovation: A Strategic Alignment Perspective, Information and Management (2014), http://dx.doi.org/10.1016/j.im.2014.12.005

This is a PDF file of an unedited manuscript that has been accepted for publication. As a service to our customers we are providing this early version of the manuscript. The manuscript will undergo copyediting, typesetting, and review of the resulting proof before it is published in its final form. Please note that during the production process errors may be discovered which could affect the content, and all legal disclaimers that apply to the journal pertain. 


\title{
Information Technology and Open Innovation: A Strategic Alignment Perspective
}

\author{
Tingru Cui \\ University of Wollongong \\ School of Information Systems and Technology \\ Northfields Avenue, NSW, Australia, 2522 \\ Tel: +61-2-4221-3491 \\ Fax: +61-2-4221-5474 \\ Email: tingru@uow.edu.au
}

Hua (Jonathan) Ye

The University of Auckland

Department of Information Systems and Operations Management

The University of Auckland Business School

12 Grafton Road, Auckland 1142, New Zealand

Tel: +64-9-373-7599

Fax: +64-9-373-7430

Email: jonathan.ye@auckland.ac.nz

\section{Hock Hai Teo}

National University of Singapore

School of Computing

15 Computing Drive, 117418, Singapore

Tel: +65-6516-2979

Fax: $+65-6779-4580$

Email: teohh@comp.nus.edu.sg

\section{Jizhen Li}

Tsinghua University

School of Economics and Management

Beijing 100084, China

Tel: +86-10-6277-2539

Fax: +86-10-6278-5876

Email: lijzh@sem.tsinghua.edu.cn 


\begin{abstract}
The advances in information technology (IT) have enabled firms to increasingly rely on open innovation. Although researchers and practitioners are interested in this phenomenon, there is a lack of theoretically driven research on how IT impacts organizational open innovation performance. Drawing on the strategic IT alignment perspective and related literature, we proposed a model to explain the performance of organizational open innovation, i.e., the alignment between IT strategies and openness of open innovation strategies results in different outcomes for open innovation. Through the analysis of data from 225 firms in China, we found that the alignment between IT flexibility and breadth enhances innovation radicalness and innovation volume while the alignment between IT integration and depth positively affects innovation volume only. Innovation volume and radicalness were found to enhance organizational performance, in terms of sales growth. Our study contributes to the literature on open innovation and strategic alignment. Its findings also have important managerial implications for practitioners.
\end{abstract}

Keywords: Open Innovation, Strategic IT Alignment, IT Flexibility, IT Integration, Innovation Radicalness, Innovation Volume 


\section{Introduction}

The phenomenal advances in information technology (IT) have rendered organizational boundaries so porous that knowledge can be easily transferred inward and outward (Whelan et al. 2010). As a result, firms need external as well as internal knowledge to compete (Boudreau and Lakhani 2009). This gives open innovation increasing momentum through management intervention, which results in "the use of purposive inflows and outflows of knowledge to accelerate internal innovation, and expand the markets for external use of innovation, respectively" (Chesbrough et al. 2006, p.1). Open innovation has been expected to bring significant benefits to firms (Chesbrough 2003a), e.g., sourcing novel ideas (Soukhoroukova et al. 2012), obtaining complementary knowledge for innovation (Huston and Sakkab 2006), or engaging customers in value co-creation (Conboy and Morgan 2011; Sawhney et al. 2005).

Despite the potential benefits of open innovation, firms have encountered difficulties in successfully carrying out open innovation initiatives (Huston and Sakkab 2006; Sarker et al. 2012). A survey of 107 European firms showed that $48 \%$ of managers were concerned with the difficulty of incorporating external knowledge into an innovation process (Enkel et al. 2009). It is noted that significant internal supporting resources are needed to unlock open innovation's potential to contribute to innovation performance (Chesbrough and Garman 2009). As an important organizational resource with a great penetration in the open innovation context, IT provides the conditions for open innovation deployment (Cui et al. 2012; Dodgson et al. 2006). For example, firms rely on online communities to actively search for potential external knowledge (Di Gangi and Wasko 2009), and the virtual environment of knowledge transfer and integration is supported by collaborative innovation systems or communication tools (Zammuto et al. 2007). However, limited information systems (IS) research has theoretically modeled and empirically examined how firms can mobilize their IT resources to support open innovation for optimal innovation performance, i.e., use the corresponding IT strategy for open innovation. IT 
strategy refers to the use of IT to support business operation and strategy (Brady and Targett 1995; Duhan et al. 2001; Hidding 2001). Due to the importance of IT in enabling open innovation initiatives, the effects of IT strategy on the performance of open innovation requires investigation.

Previous literature finds that IT strategy needs to align with organizational strategy to obtain optimal performance (Henderson and Venkatraman 1993; Reich and Benbasat 2000). In the context of this study, the pursuit of different open innovation strategies may require support from corresponding IT strategies. Appropriate IT strategies will allocate required resources to support the implementation of organizational strategies and hence enhance their performance (Tallon and Pinsonneault 2011), e.g., open innovation strategy. However, previous theories in open innovation literature cannot explain the influences of IT strategies aligning with open innovation strategy. In other words, although aligning IT strategies with open innovation strategy is likely to impact organizational open innovation, limited research has theoretically examined and empirically tested how IT strategies align with open innovation strategy to affect innovation performance. Furthermore, little research has delved into the underlying causal mechanisms of open innovation performance. Our study incorporates two intermediary innovation outcomes (radicalness and volume) and employs actual, rather than perceptual, measures of organizational performance (sales growth) to assess their effects.

In this study, we aim to fill the research gap by addressing the research question: How does the alignment of IT strategies and open innovation strategies impact organizational innovation performance, in terms of innovation radicalness and volume, and consequently the organizational performance, i.e., in terms of sales growth? This study draws on the strategic IT alignment perspective to explain the impacts of the alignment between IT strategy and open innovation strategy on organizational innovation performance. Specifically, IT flexibility and IT integration are studied to reflect organizational IT strategy (Rai and Tang 2010; Saraf et al. 2007), while the breadth and depth of openness is derived to reflect the features of open innovation strategy 
(Laursen and Salter 2006). We theorize that a better organizational innovation performance is achieved when a firm's IT strategy aligns with its open innovation strategy.

In the following section, we discuss the concepts of breadth and depth in open innovation literature, and provide an overview of the strategic IT alignment perspective as our theoretical foundation. Subsequently, we develop the research model and hypotheses. We then test our hypotheses using data collected from 225 firms. Finally, we conclude this paper with a discussion of its limitations, contributions and implications.

\section{Conceptual Background}

This section first reviews previous open innovation and strategic IT alignment literature to establish the theoretical foundation for this paper. From this, we then identify the relevant constructs and include them in our model to explain the outcomes of open innovation.

\section{Open Innovation Strategies}

Past literature has suggested three open innovation approaches, i.e., inbound open innovation, outbound open innovation, and coupled processes (Gassmann and Enkel 2004). Inbound open innovation is the practice of leveraging the discoveries of others (Chesbrough and Crowther, 2006). Through searching, acquiring and integrating external knowledge or technology into internal R\&D operation or licensing-in external technology, firms can unlock the potential of internal innovation into commercialization or learn new ways to reconfigure the existing knowledge allocation and exploitation for innovation (Chesbrough 2003; 2006).

Outbound open innovation refers to externally commercializing a firm's innovation through licensing-out, spin-offs, joint ventures, or alliances. It suggests that firms can look for external firms with business models that are suited to commercialize a technology exclusively or in addition to its internal application (Chesbrough and Crowther, 2006). 
A coupled process includes integrating external knowledge and competencies while externalizing the firm's knowledge and competencies. In order to do this, firms which utilize the coupled process innovate using a co-creative process involving (mainly) complementary partners through alliances, cooperation, and joint ventures, during which cooperation is crucial for success.

In this study, we focus on firms' open search behavior for innovation outcomes, i.e., searching an external actors and sources to help them achieve and sustain innovation (Enkel et al. 2009). This involves searching, acquiring and integrating external knowledge or technology into internal R\&D or co-creating with external partners (Laursen and Salter 2006). Therefore, this study focuses on external search under the inbound open innovation approach.

\section{External Search for Open Innovation}

With the increasing trend towards connectivity and cooperation, a new model of innovation has been catching momentum, i.e., open innovation. Firms have increasingly changed the way they search for new ideas, adopting open search strategies that involve the use of a wide range of external actors and sources to help them achieve and sustain innovation (Enkel et al. 2009). These external sources include customers, suppliers, universities, research institutions, industry consortia, and even rival firms, and many more (Chesbrough 2003b).

Firms may differ in the open innovation strategies which they adopt by searching among distinct external sources. The extent to which firms draw from external knowledge sources reflects external search openness that is required for searching external knowledge to innovate (Laursen and Salter 2006). It includes the breadth and depth of search openness (Laursen and Salter 2006). Breadth of search openness refers to the number of external sources on which a firm taps for innovation. Depth of search openness refers to the extent to which a firm deeply draws from external sources. In other words, breadth reflects the diversity of external sources a firm has searched while depth reflects the intensity of relying on them. 
Prior open innovation literature has found that firms may adopt different degrees of organizational external search openness (Dittrich and Duysters 2007; van de Vrande et al. 2009), may result in variances in organizational innovation performance. Organizational innovation performance includes two distinct aspects, i.e., innovation radicalness (i.e., innovativeness of new products) and innovation volume (i.e., the number of new products introduced) (Ettlie et al. 1984). Although extant open innovation literature enriches our understanding of the phenomenon, little research has investigated how firms adopt IT strategies to support the implementation of external knowledge for innovation. Therefore, in this study, we posit that the effect of search openness (i.e., breadth vs. depth) on organizational innovation performance will depend on its alignment with organizational IT strategies, which will be described in the next section.

\section{Strategic IT Alignment Perspective and IT Strategies}

In IS literature, strategic IT alignment is viewed as the fit between information technology and business strategy (Henderson and Cockburn 1994; Tallon and Pinsonneault 2011). According to this perspective, the strategic IT alignment can enable firms to use IT to facilitate a business strategy and obtain better performance (Delery and Doty 1996). The strategic IT alignment literature argues that a shared understanding between IT and business executives enables a more effective resource allocation to respond to environmental threats and opportunities (Gibson and Birkinshaw 2004; Tallon and Pinsonneault 2011), e.g., innovation (Chan et al. 1997). It posits that IT needs to be embedded in key business activities, which will change if a rapid shift in strategic focus is exerted by environmental forces (Tallon and Pinsonneault 2011). Aligning IT resources with business activities allows for rapid responsiveness to environmental changes (Allen and Boynton 1991) and hence a better performance (Kearns and Lederer 2004). Furthermore, strategic IT alignment can better direct organizational attentions by allocating IT resources to support business activities and hence improve organizational performance (Croteau and Bergeron 2001). The effects of alignment has been empirically examined by previous studies 
which found that alignment affects performance in general (Chan et al. 1997; Choe 2007; Geissler et al. 2001; Kearns and Lederer 2004; Oh and Pinsonneault 2007), and in critical areas such as sales growth and innovation (Chan et al. 1997; Croteau and Bergeron 2001).

In the context of innovation, with advancements in IT applications, firms are able to actively use them to engage in innovation virtually with other distant firms (LaValle et al. 2011; Nambisan 2002). Among all IT strategies, IT integration (Rai et al. 2006) and IT flexibility (Byrd and Turner 2001; Ray et al. 2005) are widely considered as the two central IT strategies in prior literature (Langdon 2006; Rai and Tang 2010). On the one hand, IT flexibility enables firms to quickly and economically adapt IT applications to support evolving knowledge sharing requirements with external sources (Gosain et al. 2004; Byrd and Turner 2000; Langdon 2006). On the other hand, Research on inter-organizational knowledge sharing has shown that IT integration facilitates the timely and idiosyncratic exchange of knowledge with collaborative partners (Grover and Saeed 2007; Rai et al. 2006). IT integration reflects tight linkages between collaboration innovation partners' IT infrastructures (Dent 2003, Grover and Saeed 2007, Rai et al. 2006). It thus contributes a mechanism to support bilateral governance (relational structures), wherein both organizations invest in establishing a coordination-intensive configuration. In this study, we posit that the IT strategy can complement each dimension of open innovation strategy, thus impacting organizational innovation (both innovation radicalness and volume) and organizational performance.

\section{Research Model and Hypotheses Development}

We draw on the strategic IT alignment perspective and open innovation literature to explain the influence of the alignment between IT strategy (i.e., IT flexibility and IT integration) and search openness (i.e., breadth and depth) on organizational innovation performance, i.e., innovation radicalness and volume. Innovation radicalness refers to the extent to which the innovations are 
different from current offerings (Ordanini and Parasuraman 2011). Additionally, we expect that the innovation performance will influence organizational performance, in terms of sales growth. Figure 1 shows the research model.

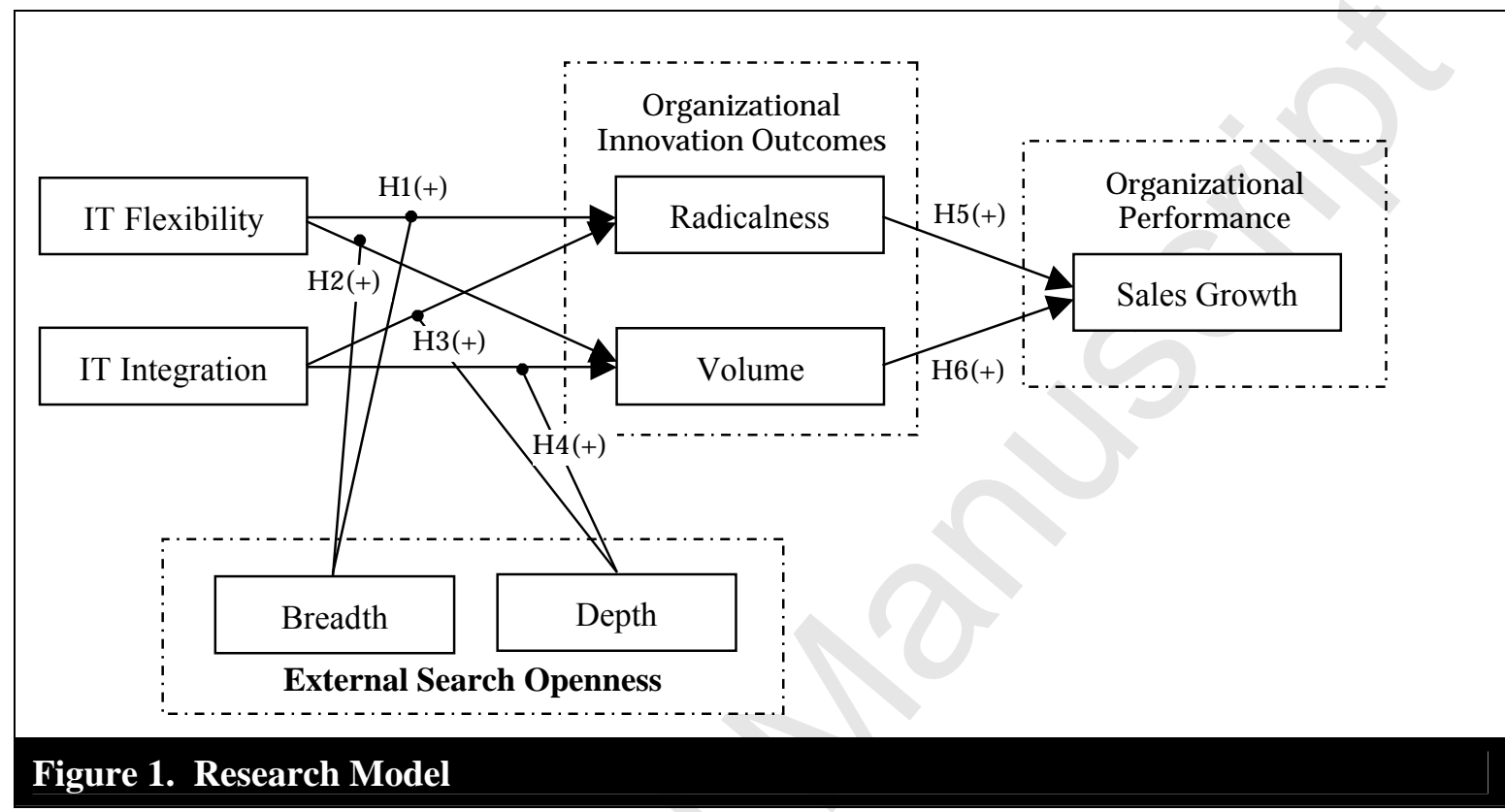

\section{IT Flexibility and External Search Breadth}

IT flexibility refers to the ability to quickly and economically adapt IT applications to support evolving requirements and manage knowledge sharing with external sources (Kumar 2004; Langdon 2006). Extant inter-organizational systems literature suggests that operating a flexible IT infrastructure influences a firm's capability to take competitive actions (Byrd and Turner 2000). For firms with a wide open innovation scope, the ability to quickly switch external innovation partners is important. Flexible IT infrastructures are compatible and modular; they can be quickly reconfigured to provide seamless and consistent access to exchange relevant knowledge among different external sources (Bharadwaj et al. 2007). Thus, high IT flexibility enables firms to obtain knowledge from a wide range of external partners through quickly adjusting IT applications. In contrast, low IT flexibility may lock firms into an unprofitable relationship with limited external sources (Saraf et al. 2007), thereby causing failure to leverage a wide scope search for innovation. Evidently, IT flexibility supports firms to leverage a broad range of 
external sources for open innovation (i.e., external search breadth), the alignment between IT flexibility and search breadth enhances the performance of open innovation.

Previous creativity research has recognized that knowledge source diversity increases the likelihood of producing innovative ideas (Amabile 1988; Amabile 1996; Hennessey and Amabile 2010), i.e., idea radicalness. Wide exposure to a large number of external knowledge sources enables firms to obtain knowledge from a variety of disciplines and domains (Prabhu et al. 2005), and to recombine diverse knowledge for more radical innovations. Also, it provides distinct modes of reasoning, and varied problem-solving approaches (Ahuja and Morris Lampert 2001). Hence, supported by flexible IT, firms can draw heterogeneous knowledge from a wide search of external sources and recombine it for more radical innovations (Zahra and George 2002). Based on the above reasoning, we argue that the alignment of IT flexibility and external search breadth enables firms to allocate flexible IT resources to obtain diverse knowledge exchange and enhance the introduction of new products or services that differ significantly from the existing ones (i.e., more radically innovative products). We thus propose:

H1: The alignment between IT flexibility and external search breadth is positively associated with innovation radicalness.

A high volume of innovations can be achieved through knowledge recombination efficiency and an organizational culture of change (Gibson and Birkinshaw 2004), which may result from the alignment of IT flexibility and external search breadth. Firstly, prior research suggests that the novel recombination of knowledge elements leads to the creation of new knowledge (Hall and Hall 1969; Nelson and Winter 1982). Drawing knowledge from diverse sources provides firms with more knowledge recombination opportunities. IT flexibility enables firms to quickly switch from one knowledge source to another, consequently, obtaining diverse knowledge and leading to higher efficiency of knowledge recombination. The alignment of IT flexibility and external 
search breadth thus enables a wide range of knowledge to be exchanged and integrated efficiently, leading to greater knowledge creation. We therefore expect that the alignment increases the number of innovations within a given time frame.

Second, such an alignment of IT flexibility and external search breadth infuses a culture of change within the entire firm, which stimulates ongoing and systematic analysis and modification of the status quo (Croteau and Bergeron 2001; Vance et al. 2008). It therefore creates an overall context in which more innovations can take place rapidly. Thus, combining the discussion above, we expect the alignment of IT flexibility and external search breadth to enhance the volume of innovations. Thus we hypothesize:

H2: The alignment between IT flexibility and external search breadth is positively associated with innovation volume.

\section{IT Integration and External Search Depth}

A second strategy salient in the context of IT-enabled open innovation behaviors is IT integration. In this study, IT integration is defined as the ability of a firm to integrate data, communication technologies, and collaboration applications with its external knowledge sources (Barua et al. 2004; Rai and Tang 2010). IT integration reflects tight linkages between collaboration innovation partners' IT infrastructures and has been identified as a key agent of the business value that a firm can realize from its collaborative innovation relationships (Rai et al. 2006).

However, in our arguments to be presented in the next section, we theorize that this strategy aligns with external search depth, rather than external search breadth to affect organizational innovation performance. Previously, we stressed that the concept of external search depth is defined as the extent to which firms draw intensively from different search channels or sources of innovative ideas (Laursen and Salter 2006). Hence, it reflects the importance of the in-depth use of key sources to the internal innovation process. For each of these sources, firms need to sustain 
a pattern of interaction over time, building up a shared understanding and common ways of working together (Leana and Van Buren 1999). As suggested by prior literature, the deep open innovation pattern increases behavioral interdependence between the focal firm and its key sources (Tiwana 2008). This requires firms to engage in timely and idiosyncratic exchanges of knowledge with their innovation partners in their open innovation processes. An integrated IT infrastructure enables a firm to share information, coordinate activities, and align processes with its partners (Grover and Saeed 2007). Thus, we expect that IT integration supports the external search depth and this alignment affects both innovation radicalness and volume.

In particular, with the support of integrated IT, drawing extensively on given knowledge sources facilitates the exchange of tacit knowledge and the introduction of radically new products. The alignment assists a firm to maintain strong and frequent contacts with closely tied external partners and encourages the exchange and integration of fine-grained and in-depth tacit knowledge (Leana and Van Buren 1999). Such assimilation and absorption of tacit knowledge together with internal knowledge facilitates the creation of radical innovations (Gibson and Birkinshaw 2004).

In the context of open innovation, in a similar vein, we posit that the alignment of IT integration and the intensive drawing on of ideas will be conducive to more radical innovation. This is because the alignment may reinforce firms' ability to develop social capital with its partners, which serves as the foundation for radical innovation. Social capital appears as resources generated by intensive collaboration and interaction among interpersonal networks and enhances innovation (Nahapiet and Ghoshal 1998). By activating IT integration with a small number of external knowledge providers repeatedly, firms closely interact with their partners. This may increase inter-organizational cohesion and mutual support, and cultivate a benign environment for radical innovations (Huang and Li 2009; López-Cabrales et al. 2008). 
In addition, radical innovations are characterized by high uncertainty/complexity (Gopalakrishnan et al. 2006). Given that the uncertainty/complexity associated with radical innovations increases the difficulty of decision making, high quality relationships among those involved (i.e., high social capital) - that may be derived from the alignment between IT integration and external search depth — could help achieve the necessary agreements and collaboration for radical innovation. Accordingly, we hypothesize:

H3: The alignment between IT integration and external search depth is positively associated with innovation radicalness.

Furthermore, we posit that this alignment positively influences innovation volume. First, firms benefit from having in-depth connectivity and integration with a number of knowledge sources because this enables the accumulation of mutual knowledge (Kang et al. 2007). Collaborative firms with strong ties accumulated over time gain a thorough reciprocal knowledge of each other's resources, technical know-how, design competencies, and organizational routines, together with integrated IT and long-term objectives. This facilitates the speed and likelihood of knowledge access and exchange, and the depth of knowledge interpretation. The results are (1) a reduction of the time taken for overall product or service development and (2) an increase in innovation volume.

Second, the alignment of IT integration and external search depth may boost inter-organizational trust and reciprocity, and enhance the underlying interpersonal relationships between individual members of partnering firms (Gibson and Birkinshaw 2004). Firms involved in strong, trustbased relationships are willing to pool their assets and to share knowledge (Zahra and George 2002). Once such a collaborative atmosphere has been created, an efficient collaboration process is facilitated and this results in the introduction of more products or services. Therefore, IT 
integration and external search depth is likely to have a positive effect on the innovation volume. We therefore posit:

H4: The alignment between IT integration and external search depth is positively associated with innovation volume.

\section{Innovation Performance and Organizational Performance}

The introduction of new products or services is a critical determinant of organizational performance (Damanpour 1991). On the one hand, by introducing new products or services, firms can establish new markets and technologies (Burgelman 1991). Research has demonstrated that new products or services improve the market share, market value, and survival of firms (Banbury and Mitchell 1995; Chaney and Devinney 1992). Innovation provides firms with a new method of conducting business ahead of competition and the potential to gain a competitive edge in the marketplace (Ahuja 2000). On the other hand, a stream of new products or services enables firms to diversify, adapt, and reinvent themselves to meet new market demands (Brown and Eisenhardt 1995). Innovation provides firms with a new means of meeting customer needs and this can lead to increased financial performance. Thus, we expect the radicalness and volume of organizational innovation to be positively related to the organizational performance. Accordingly, we hypothesize:

H5: Innovation radicalness is positively associated with organizational performance.

H6: Innovation volume is positively associated with organizational performance.

\section{Research Methodology}

The survey approach was used to test the model. Our sampling frame included firms from four industries that have a broad presence in China's economy (in industries of the following sectors: chemical and pharmaceutical, electronic and other electrical equipment, industrial and commercial machinery equipment, and fabricated metal and other materials). We followed the 
key informant approach to collect data from one R\&D manager at each firm because executives in these roles were most likely to be knowledgeable about the items dealt with in our survey (Phillips and Bagozzi 1986). We approached these managers in January 2013. Considering the objective of this study, we selected high-tech firms that have participated in open innovation projects to co-develop a new product with external collaborators.

\section{Construct Measurement and Questionnaire Development}

The survey instrument was adapted from existing validated scales. We used objective data to measure the organizational performance (see Table 1). Sales growth was measured through the increase of annual sales compared to the previous year, as was the procedure in prior studies (Cooper and Kleinschmidt 1995).

To determine the innovation volume, we asked the respondents to report the number of new products or services introduced in the given year. The use of objective measures can help reduce the risk of common method variance and hence increase the validity of our findings (Podsakoff et al. 2003). To measure innovation radicalness, IT flexibility and IT integration, we adapted items respectively, based on prior literature. The results are presented in Table 1. Items for the three constructs were measured using 7-point Likert scales ranging from "strongly disagree" to "strongly agree".

We adapted the measure of search openness from Laursen and Salter (2006) through in-depth consultations with eleven R\&D managers from nine Chinese firms. Following Laursen and Salter (2006), twelve knowledge sources were adopted in this study according to the research context. We asked the corresponding R\&D managers to indicate on a scale of 1-7 "the extent to which they drew ideas for innovation" from each of the knowledge sources if they have used the knowledge source for innovation. The measure of external search breadth was calculated as a sum across all 12 sources. Firstly, each of the 12 sources was coded as a binary variable, "0" 
indicating it was not used and "1" indicating that it was used. Subsequently, the 12 sources were added up so that a firm is given a "0" when no knowledge sources are used, while a firm is given a value of "12", if all knowledge sources are used. We coded the value of external search depth for each source as "1", if the value for using each knowledge source for innovation was 5 or above; otherwise " 0 ". Next organizational external search depth was calculated as a sum across all 12 sources. The value of external search depth indicates the number of channels from which the focal firm intensively sources ideas for innovations. Please see the mathematical notation for the two measures below.

$$
\text { Breadth }=\sum_{n=1}^{12}\left(b_{n}\right) ; \text { Depth }=\sum_{n=1}^{12} f\left(a_{n}\right)
$$

Here, $b_{n}$ is the value of whether the knowledge source $n$ is used or not. If used, the value is 1 , otherwise $0 . a_{n}$ is the value of using knowledge source $n . f\left(a_{n}\right)$ is the value of depth coded for each source. It is coded 0 if $a_{n}$ is less than 5 , otherwise 1 .

We use the moderation approach to measure the alignment between the IT strategies and open search strategies since it is more effective in measuring alignment than the matching approach (Chan et al. 1997; Chan and Reich 2007; Cragg et al. 2001). We calculate the alignment using interaction terms as suggested by Chan et al. (1997).

We control for the effects of firm age, size, industry and R\&D intensity on a firm's innovation outcomes and performance. Prior literature suggests that organizational performance may be influenced by its internal organizational and $R \& D$ characteristics. Thus, firm age, size and $R \& D$ intensity are included as control variables in the model (He and Wong 2004). As organizational performance also depends in part on the external environment in which the firm operates, the effect of industry sector is also controlled (Rai and Tang 2010). Hence they are included as control variables (see Table 1). 
Table 1. Operationalization of Constructs

\begin{tabular}{|c|c|c|}
\hline Variables & Item Description & Reference \\
\hline $\begin{array}{l}\text { Breadth and } \\
\text { depth (coded } \\
\text { from } 12 \\
\text { sources) }\end{array}$ & $\begin{array}{l}\text { ( } 1-7 \text { scale: } 1=\text { Not at all, } 7=\text { Extensively high) } \\
\text { - Suppliers of equipment, materials, components, or software } \\
\text { - Clients or customers } \\
\text { - Competitors } \\
\text { - Consultants } \\
\text { - Commercial laboratories/R\&D enterprises } \\
\text { - Universities or other higher education institutes } \\
\text { - Research institutes } \\
\text { - Public sector, e.g., business links, government offices } \\
\text { - Professional conferences, meetings } \\
\text { - Trade associations } \\
\text { - Technical/trade press, computer databases } \\
\text { - Fairs, exhibitions }\end{array}$ & $\begin{array}{l}\text { Adapted from } \\
\text { Laursen and } \\
\text { Salter }(2006)\end{array}$ \\
\hline IT flexibility & $\begin{array}{l}\text { ( } 1-7 \text { scale: } 1=\text { Strongly disagree, } 7=\text { Strongly agree) } \\
\text { - The manner in which the components of the IT systems used in our open } \\
\text { innovation activities are organized and integrated to allow for rapid } \\
\text { changes. } \\
\text { - The IT systems used in our open innovation activities are highly scalable. } \\
\text { - The IT systems used in our open innovation activities are designed to } \\
\text { support new collaborative innovation relationships easily. } \\
\text { - The IT systems used in our open innovation activities can be easily } \\
\text { extended to accommodate new applications or functions. }\end{array}$ & $\begin{array}{l}\text { Adapted from } \\
\text { Fichman } \\
\text { (2004); Saraf } \\
\text { et al. (2007) }\end{array}$ \\
\hline IT integration & $\begin{array}{l}\text { ( } 1-7 \text { scale: } 1=\text { Strongly disagree, } 7=\text { Strongly agree) } \\
\text { - The IT systems used in our open innovation activities can easily access } \\
\text { data from innovation collaborators' systems. } \\
\text { - The IT systems used in our open innovation activities provide seamless } \\
\text { connection to our innovation collaborators' systems. } \\
\text { - The IT systems used in our open innovation activities have the capability } \\
\text { to exchange real-time information with innovation collaborators. } \\
\text { - The IT systems used in our open innovation activities easily aggregate } \\
\text { relevant information from our innovation collaborators' databases. }\end{array}$ & $\begin{array}{l}\text { Adapted from } \\
\text { Barua et al. } \\
\text { (2004); Rai } \\
\text { and Tang } \\
(2010)\end{array}$ \\
\hline Radicalness & $\begin{array}{l}\text { ( } 1-7 \text { scale: } 1=\text { Strongly disagree, } 7=\text { Strongly agree }) \\
\text { - We are renowned in the industry for our new breakthrough products or } \\
\text { services. } \\
\text { - We lead the way in introducing product or service innovations that } \\
\text { require brand new competences. } \\
\text { - We constantly introduce new products or services that satisfy future } \\
\text { market needs. }\end{array}$ & $\begin{array}{l}\text { Adapted from } \\
\text { Chandy and } \\
\text { Tellis (2008) }\end{array}$ \\
\hline Firm age & The number of years since its establishment. & \multirow{2}{*}{$\begin{array}{l}\text { Adopted from } \\
\text { He and Wong } \\
(2004)\end{array}$} \\
\hline Firm size & The number of employees in the firm. & \\
\hline $\mathrm{R} \& \mathrm{D}$ intensity & The annual R\&D expenditures of the firm. & $\begin{array}{l}\text { Adopted from } \\
\text { Laursen and } \\
\text { Salter (2006) }\end{array}$ \\
\hline Industry & $\begin{array}{l}\text { Four industries that have a broad presence in China's economy (Chemical } \\
\text { and pharmaceutical, electronic and other electrical equipment, industrial } \\
\text { and commercial machinery equipment, and transportation equipment } \\
\text { industries). }\end{array}$ & $\begin{array}{l}\text { Adapted from } \\
\text { Rai and Tang } \\
(2010)\end{array}$ \\
\hline
\end{tabular}


Our survey instrument was refined as follows. First, to enhance the conceptual validity, we conducted a two-stage Q-sorting. As suggested by Moore and Benbasat (1991), two-step Qsorting is useful to verify the content validity, convergent validity and discriminant validity of measures. Twelve Ph.D. students were recruited from the department of information systems at a large university in Singapore. In the unlabeled and labeled sorting sessions, they correctly classified $91 \%$ and $97 \%$ of the items into the intended constructs. The results show the good quality of the measures.

Second, the items were reviewed by several colleagues to identify and rectify potential problems due to the framing and phrasing of the questions. Next, the questionnaire was translated into Chinese. To ensure comparability and equivalence in meaning, the method of back-translation was adopted (Brislin 1970). Two graduate students conducted the translation work independently. The authors compared the translated version with the original one and made changes when necessary. In addition, three $R \& D$ managers who were involved in managing open innovation projects at their respective firms reviewed the questionnaire and commented on its content validity, terminology, clarity of instructions, and response formats. Minor modifications were made on some items to address the concerns.

\section{Data Collection}

We followed the key informant approach to collect data from one R\&D manager at each firm (Phillips and Bagozzi 1986). R\&D managers were requested to answer the questionnaire based on their organizational conditions in the year 2012 for some questions (data collection was conducted in January 2013). To ensure the quality of the data, we collaborated with a Chinese government agency (Municipal Science and Technology Commission) to send out survey invitations. Of the 733 R\&D managers who received the invitations, 248 surveys were returned. Among returned surveys, $23 \mathrm{R} \& \mathrm{D}$ managers reported their firms did not engage in open innovation activities; hence they were eliminated from the sample. Finally, 225 completed 
surveys were received. This represents a response rate of $30.7 \%$. On average, the R\&D managers had been in their positions for 8.1 years (standard deviation (S.D.) $=5.7)$.

Among the received surveys, 52 respondent firms are located in Beijing and 173 respondent firms in Jiangxi province. We tested the non-response bias by comparing demographic characteristics between the respondent and non-respondent firms and responses on principal constructs between $10 \%$ earlier respondents and 10\% later respondents. All t-tests between the means of the two groups showed no significant differences $(\mathrm{p}<0.05)$. Considering the data were collected from multiple locations without significant differences, our sample should be representative of Chinese manufacturing firms. A summary of the information regarding the industry wide distribution of the sample, the size and annual sales of the firms is presented in Table 2.

\section{Table 2. Demographic Profile of the Sample $(\mathrm{N}=225)$}

\begin{tabular}{|l|l|l|l|}
\hline \multirow{4}{*}{ Industry } & & No. of Firms & Percentage \\
\cline { 2 - 4 } & Chemical and pharmaceutical & 47 & 22.9 \\
\cline { 2 - 4 } & Electronic and other electrical equipment & 57 & 25.3 \\
\cline { 2 - 4 } & $\begin{array}{l}\text { Industrial and commercial } \\
\text { machinery equipment }\end{array}$ & 57 & 25.3 \\
\cline { 2 - 4 } & Fabricated metal and other material & 64 & 28.4 \\
\hline \multirow{4}{*}{$\begin{array}{l}\text { Firm Size } \\
\text { Number of Employees) }\end{array}$} & $<100$ & 43 & 19.1 \\
\cline { 2 - 4 } & $100-249$ & 71 & 31.6 \\
\hline \multirow{5}{*}{ Sales (Millions) } & $250-499$ & 57 & 25.3 \\
\cline { 2 - 4 } & $500-1,000$ & 24 & 10.7 \\
\cline { 2 - 4 } & $>1,000$ & 30 & 13.3 \\
\hline & $<10$ & 10 & 4.4 \\
\cline { 2 - 4 } & $10-100$ & 87 & 38.7 \\
\cline { 2 - 4 } & $100-500$ & 23 & 37.3 \\
\cline { 2 - 4 } & $500-1,000$ & 21 & 10.2 \\
\hline & $>1,000$ & 8.3 \\
\hline
\end{tabular}

To assess the non-response bias, we conducted two tests. First, we verified that the $10 \%$ of early and late respondents did not significantly differ in their demographic characteristics and 
responses on principal constructs. All t-tests between the means of the two groups showed no significant differences $(\mathrm{p}<0.01)$. Second, we compared the difference between the expected and observed number of responses across the four industries in our sampling frame. The chi square test results showed no significant differences $(\mathrm{p}<0.01)$. Hence, the two tests did not suggest any evidence of response bias in the collected data.

Since our dependent variables were objective measures from the firms' self-reported archival revenues information, the common method bias was not a major concern in this study. To further verify the accuracy of the respondent firms' self-reported information, we obtained the annual reports of 20 firms in our sample from the public listed company database ${ }^{1} .100 \%$ agreement has been observed between the self-reported information and that in the annual reports.

\section{Data Analysis and Results}

For this study, structural equation modeling (SEM) analysis was chosen since it can simultaneously analyze all paths with latent variables within one analysis (Gefen et al. 2011). Within SEM, Partial Least Squares (PLS) was chosen over co-variance based SEM for two reasons. First, the dependent variables were measured with archival data, which might not conform to the proportionality constraints and uncorrelated measurement errors of co-variance based SEM (Gefen et al. 2011). Second, PLS is a suitable choice for the model with interaction effects as in our model (Wetzels et al. 2009). Interaction terms were computed by crossmultiplying the standardized items of the relevant constructs. We used SmartPLS 2.0 to analyze the data.

\section{Instrument Validity}

To validate our instrument, convergent and discriminant validities were tested (Hair et al. 2006). We assessed convergent validity by examining the Cronbach's $\alpha$ (CA) ( $>0.7)$, composite

\footnotetext{
1 We use self-reported data because not all firms have filed IPOs.
} 
reliability $(>0.7)$, average variance extracted (AVE) $(>0.5)$, and factor analysis results (Straub et al. 2004).

\section{Table 3. Factor Loadings and Descriptive Statistics}

\begin{tabular}{|c|c|c|c|c|c|c|}
\hline & 1 & 2 & 3 & CA & CR & AVE \\
\hline FLEX1 & 0.94 & 0.44 & 0.49 & \multirow[t]{4}{*}{0.96} & \multirow{4}{*}{0.97} & \multirow{4}{*}{0.88} \\
\hline FLEX2 & 0.93 & 0.41 & 0.46 & & & \\
\hline FLEX3 & 0.94 & 0.44 & 0.51 & & & \\
\hline FLEX4 & 0.95 & 0.41 & 0.52 & & & \\
\hline INTE1 & 0.37 & 0.87 & 0.16 & \multirow[t]{4}{*}{0.93} & & \multirow[t]{4}{*}{0.83} \\
\hline INTE2 & 0.44 & 0.93 & 0.24 & & & \\
\hline INTE3 & 0.43 & 0.93 & 0.21 & & & \\
\hline INTE4 & 0.41 & 0.92 & 0.26 & & & \\
\hline RADI1 & 0.53 & 0.22 & 0.95 & \multirow[t]{3}{*}{0.89} & \multirow{3}{*}{0.93} & \multirow[t]{3}{*}{0.82} \\
\hline RADI2 & 0.41 & 0.18 & 0.88 & & & \\
\hline RADI3 & 0.49 & 0.25 & 0.90 & & & \\
\hline
\end{tabular}

\section{Table 4. Correlations}

\begin{tabular}{|c|c|c|c|c|c|c|c|}
\hline & Breadth & Depth & IT Flexibility & \begin{tabular}{|l|} 
IT \\
Integration
\end{tabular} & Radicalness & Volume & \begin{tabular}{|l|} 
Sales \\
Growth
\end{tabular} \\
\hline Breadth & - & & & $\forall$ & & & \\
\hline Depth & 0.33 & - & & & & & \\
\hline IT Flexibility & 0.14 & 0.31 & 0.97 & & & & \\
\hline IT Integration & 0.07 & 0.27 & 0.45 & 0.91 & & & \\
\hline Radicalness & 0.46 & 0.32 & 0.52 & 0.24 & 0.91 & & \\
\hline Volume & 0.19 & 0.38 & 0.39 & 0.47 & 0.36 & - & \\
\hline Sales Growth & 0.13 & 0.43 & 0.49 & 0.32 & 0.42 & 0.41 & - \\
\hline
\end{tabular}

As the results in Table 3 show, the factor loading of each item was found to be larger than 0.7 on its own construct. In addition, all the values for CA and CR were greater than 0.7 and the values for AVE were greater than 0.5, satisfying the criteria suggested by Straub et al. (2004). These results demonstrate sufficient convergent validity for all constructs. Discriminant validity was assessed by examining the indicator-factor loadings and comparing AVEs with inter-construct correlations (Gefen and Straub 2005). The results in 
Table 3 show that all indicators load more strongly on their corresponding constructs than on other constructs in the model and the square root of AVE was larger than the inter-construct correlations in Table 4. Generally, the results demonstrate sufficient discriminant validity of all constructs.

\section{Structural Modeling}

After establishing an adequate measurement model, we used a bootstrapping procedure with 5000 subsamples to estimate the statistical significance of the hypothesized relationships using PLS (Hair et al. 2011). Figure 2 presents the results of the analysis. Tables 5 and 6 show the results of hypotheses testing. The influence of control variables was shown in Models 1 and 4, the direct effects in Models 2, 5, and 7, and the interaction effects in Models 3 and 6 . Model 3 explains $49 \%$ of the variances in innovation radicalness. None of the control variables are significant. As hypothesized, IT flexibility positively interacts with external search breadth to affect the innovation radicalness, thus supporting H1. But the interaction effect of IT flexibility and external search breadth was not significant. Hence, H3 is not supported.

Model 6 explains $42.7 \%$ of the variance in innovation volume. It shows that none of the control variables are significant. Furthermore, it also shows that the interaction effect of IT flexibility and external search breadth has a significant positive impact on innovation volume, thereby supporting H2. As hypothesized, the interaction effect of IT integration and external search depth also positively affects the volume of innovation introduction, thus supporting H4. Model 7 explains $28.6 \%$ of the variance in organizational sales growth. As hypothesized, the innovation radicalness positively affects the sales growth, thus supporting H5. The innovation volume also positively affects the sales growth, thus supporting H6. 


\begin{tabular}{|c|c|c|c|c|c|c|c|}
\hline \multirow[t]{2}{*}{ Dependent Variables } & \multicolumn{3}{|c|}{ Radicalness } & \multicolumn{3}{|c|}{ Volume } & \multirow{2}{*}{$\begin{array}{c}\begin{array}{c}\text { Sales } \\
\text { Growth }\end{array} \\
\text { Model } \\
7\end{array}$} \\
\hline & $\begin{array}{c}\text { Model } \\
1\end{array}$ & $\begin{array}{c}\text { Model } \\
2\end{array}$ & $\begin{array}{c}\text { Model } \\
\mathbf{3}\end{array}$ & $\begin{array}{c}\text { Model } \\
4\end{array}$ & \begin{tabular}{|c|} 
Model \\
5 \\
\end{tabular} & $\begin{array}{c}\text { Model } \\
6\end{array}$ & \\
\hline Control variables & & & & & & & 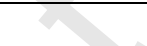 \\
\hline Firm Age & -0.11 & -0.09 & -0.06 & 0.01 & 0.02 & 0.05 & $-0.13^{*}$ \\
\hline Firm Size & 0.03 & -0.04 & -0.05 & 0.00 & -0.02 & -0.02 & -0.01 \\
\hline R\&D Intensity & -0.09 & -0.05 & -0.04 & -0.07 & -0.02 & -0.01 & -0.04 \\
\hline Industry dummy 1 & -0.04 & 0.04 & 0.05 & -0.07 & -0.05 & -0.04 & 0.01 \\
\hline Industry dummy 2 & 0.12 & -0.02 & -0.01 & 0.00 & 0.06 & -0.03 & 0.09 \\
\hline Industry dummy 3 & 0.03 & -0.03 & -0.04 & 0.01 & 0.04 & 0.03 & -0.05 \\
\hline \multicolumn{8}{|l|}{ Direct effects } \\
\hline IT flexibility & & $0.47^{* * *}$ & $0.48 * * *$ & & $0.16^{*}$ & $0.18^{*}$ & \\
\hline IT integration & & -0.01 & -0.02 & & $0.32 * * *$ & $0.30 * *$ & \\
\hline $\begin{array}{l}\text { External search } \\
\text { breadth }\end{array}$ & & $0.40^{* * *}$ & $0.46^{* * *}$ & & 0.05 & $0.14 *$ & \\
\hline $\begin{array}{l}\text { External search } \\
\text { depth }\end{array}$ & & 0.05 & 0.01 & & $0.27 * *$ & $0.20 * *$ & \\
\hline \multicolumn{8}{|l|}{ Interactions } \\
\hline $\begin{array}{l}\text { IT Flexibility* } \\
\text { External search } \\
\text { breadth }\end{array}$ & & & $0.18^{*}$ & $\gamma$ & & $0.21 *$ & \\
\hline $\begin{array}{l}\text { IT Integration* } \\
\text { External search } \\
\text { depth }\end{array}$ & & & 0.06 & & & $0.16^{* *}$ & \\
\hline \multicolumn{8}{|l|}{ Innovation Impacts } \\
\hline Radicalness & 2 & re & & & & & $0.29 * *$ \\
\hline Volume & 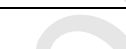 & $y$ & & & & & $0.30 * *$ \\
\hline $\mathrm{R}^{2}$ & 0.04 & 0.45 & 0.49 & 0.04 & \begin{tabular}{|l|}
0.34 \\
\end{tabular} & 0.41 & 0.29 \\
\hline $\begin{array}{l}\text { Number of } \\
\text { observations }\end{array}$ & & & & 225 & & & \\
\hline
\end{tabular}




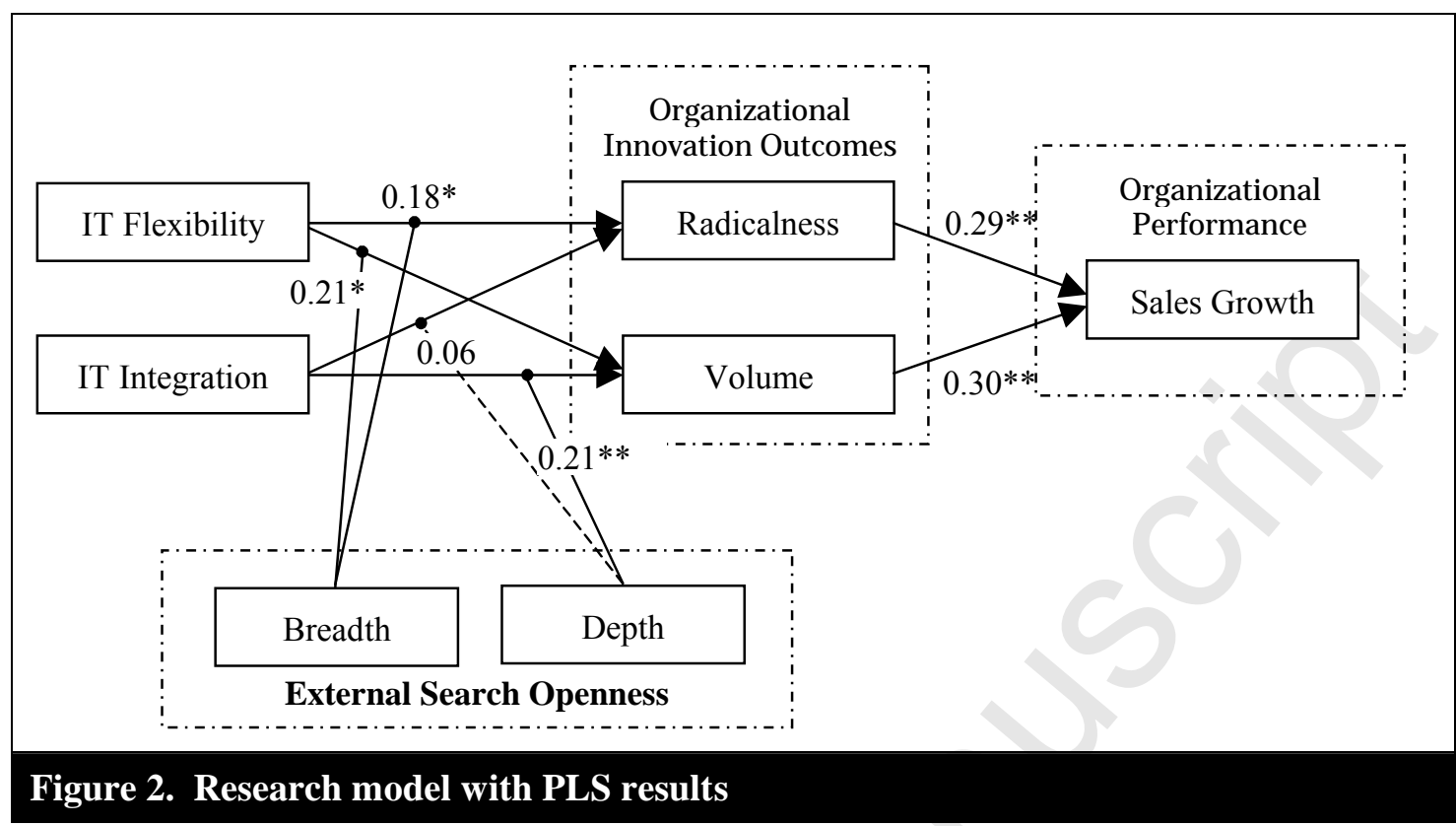

\begin{tabular}{|l|l|l|}
\hline \multicolumn{4}{|l|}{ Table 6. Summary of Hypotheses Testing } \\
\hline Number & Hypothesis & Finding \\
\hline H1 & $\begin{array}{c}\text { IT flexibility } \times \text { external search breadth } \\
\rightarrow \text { Innovation radicalness }(+)\end{array}$ & Supported \\
\hline H2 & $\begin{array}{l}\text { IT flexibility } \times \text { external search breadth } \\
\rightarrow \text { Innovation volume }(+)\end{array}$ & Supported \\
\hline H3 & $\begin{array}{c}\text { IT integration } \times \text { external search depth } \rightarrow \\
\text { Innovation radicalness }(-)\end{array}$ & Not supported \\
\hline H4 & $\begin{array}{c}\text { IT integration } \times \text { external search depth } \rightarrow \\
\text { Innovation volume }(+)\end{array}$ & Supported \\
\hline H5 & Innovation radicalness $\rightarrow$ Sales growth $(+)$ & Supported \\
\hline H6 & Innovation volume $\rightarrow$ Sales growth $(+)$ & Supported \\
\hline
\end{tabular}

\section{Post Hoc Analysis}

While our hypotheses were drawn from the strategic IT alignment perspective and open innovation literature, an additional post hoc analysis was conducted to obtain a more comprehensive view of the phenomenon and enrich our understanding. We examine the misalignment of IT strategies and open innovation strategies, which are the interaction effects of (1) IT flexibility and external search depth and (2) IT integration and external search breadth on organizational innovation outcomes, i.e., the radicalness and innovation volume. First, IT flexibility and external search depth have a negative significant interaction 
impact on the innovation volume $(\beta=-0.11, \mathrm{p}<0.05)$. However, their interaction effect on the innovation radicalness is not significant. The possible explanation is that firms with a greater external search depth need to sustain a pattern of interactions over time, requiring a shared understanding and common ways of working together with other firms. However, IT flexibility fails to provide more customized IT solutions to the specific external knowledge sources. Hence, profiting from external knowledge sources can be hampered.

Second, the interaction of IT integration and external search breadth does not have significant impact on either the volume or the innovation radicalness. The explanation is that the tight linkages supported by IT integration could lock firms' collaborations with specific collaborators and deter them from establishing new connections. Thus, any increase in the possibilities of new technologies has been diminished.

In summary, the post-hoc analysis results indicate that the misalignment of IT strategies and open innovation strategies indeed is unable to provide positive organizational innovation outcomes. Rather, the alignment of IT flexibility and external search breadth as well as IT integration and external search depth serve as the desired model for organizational open innovation practices as we hypothesized.

\section{Discussion}

This study has two key findings. First, our research suggests the enablement role of IT in supporting an open innovation model. The alignment of open innovation and IT strategies enhances open innovation performance, which contributes to organizational performance. Second, the focus of a firm's open innovation and IT strategic alignment influences the radicalness and innovation volume outcomes. The alignment between external search breadth and IT flexibility enhances the radicalness and volume of new products that a firm 
introduces to the market, while the alignment between external search depth and IT integration leads to the introduction of a greater number of new products or services.

However, we did not find a significant effect of the alignment between IT integration and external search depth on the radicalness of innovations. This finding could be because the alignment may restrict firms' ability to access new technologies and novel ideas. Over time, much of the shared knowledge becomes homogeneous and redundant (Burt 1992). Thus the innovating firms tend to engage in innovation activities in their existing, specialized domains (Christensen 2006). In addition, by activating IT integration with given external knowledge providers repeatedly, knowledge sharing accentuates its self-reinforcing cycle of competence. It reduces the likelihood of errors and facilitates the development of routines that sustain its current focus (Levinthal and March 1981). This can thus lead to norms of adhering to established standards and conventions, potentially stifling experimentation and creativity and undermining the creation of radical innovations.

\section{Limitations and Future Research}

While our study has contributed fresh insights into IT and open innovation, our findings need to be interpreted in terms of their limitations. First, the data was collected in China, which is a developing country in economic transition. However, we expect this problem to be minimal since results reported in prior organizational innovation studies that employed samples from Chinese firms (e.g., Atuahene-Gima 2005; Zhang and Li 2010) do not appear to be systematically different from those studies conducted in other countries (e.g., Leiponen and Helfat 2010). It would be useful for future research to enhance and test our model with data collected in different institutional contexts.

Another limitation of this research that warrants mention is its cross-sectional versus longitudinal nature. In particular, a longitudinal study of the effects of IT and open 
innovation strategies on firm innovation performance would have provided richer information and may enable a more accurate portrayal of the open innovation consequences. This suggests a useful avenue for additional research. However, our study with crosssectional data has its own merits in terms of identifying important relationships in the context of open innovation.

Third, although we collected data from four industries that reflect a broad presence in the Chinese economy, they were all from the manufacturing sector. Our model can be tested in other industries, including the service industry, to examine the generalizability of our findings. Fourth, though we evaluated the effects of external search breadth and depth, we did not evaluate how other network properties such as network density and firm centrality influence a firm's innovation performance. Thus, this would be another useful avenue for future research.

\section{Theoretical Contributions}

While open innovation is gaining momentum in business operations and in research, a context-specific theory is needed to extract the potential it offers. Information systems have much to contribute to the development of such a theory due to the pivotal role of IT in enabling open innovation initiatives. With the advance of IT, firms are able to engage virtually in new product development with other firms that are geographically distant (LaValle et al. 2011; Nambisan 2002). However, IS researchers have not systematically explored this phenomenon. This research adds a much needed perspective to open innovation literature by exploring the business value of IT in supporting organizational open innovation. It develops a theory for open innovation by demonstrating the strategic alignment of IT and organizational external search openness, and its impact on organizational innovation performance. 
This study contributes to the literature in several ways. First, based on the strategic IT alignment perspective, it investigates the critical role of organizational IT strategy in open innovation management. IT is valuable, but its extent and dimensions are contingent on complementary organizational business strategies (Melville et al. 2004; Wade and Hulland 2004). Researchers have suggested that IT contributes to sustainable competitive advantage through its interaction with other organizational resources (Chi et al. 2010; Melville et al. 2004). Yet, empirical research in the open innovation context is lacking. This study theoretically establishes the link between the alignment of IT strategy and open innovation strategy, and organizational innovation performance. By doing so, we have carved the path for future research on how IT can impact open innovation.

Second, this study extends the strategic IT alignment perspective. Previously, this perspective had been mainly applied to an explanation of organizational performance e.g., competitive advantage (Kearns and Lederer 2003) and sales growth and innovation (Chan et al. 1997; Croteau and Bergeron 2001). Our study widens this theoretical lens by including the features of open innovation strategy (i.e., search depth and breadth) and its applicability to the context of open innovation. Also, findings of this study provide insights into how the strategic IT alignment perspective can be amended to apply to the context of open innovation, i.e., the alignment between IT flexibility and external search depth may not have an impact on open innovation outcomes.

Third, while prior literature provides valuable insights into the indispensable enabling role of strategic IT alignment towards firms' competitive advantage (e.g., Kearns and Lederer 2004), scant attention has been devoted to its impact on different innovation outcomes (i.e., radical and incremental innovation). By drawing on the strategic IT alignment perspective, this study contributes to previous literature (e.g., Im and Rai 2008; Tallon and Pinsonneault 2011) by linking strategic IT alignment with different outcomes of open innovation strategy. 
Fourth, previous open innovation research mainly focused on the impacts of external search openness (Laursen and Salter 2006; van de Vrande et al. 2009). This paper amends these theories by finding that external search openness needs to align with organizational IT strategies in order to result in superior innovation performance. Furthermore, a large number of studies have focused on the innovation-performance relationship in the context of closed innovation (e.g., Han et al. 1998). Our study empirically tested and validated the relationship in the context of open innovation. In this sense, this study contributes to previous innovation literature by empirically supporting the innovation-performance relationship in the context of open innovation. Further, this study contributes to previous open innovation literature by investigating intermediary innovation outcomes and organizational performance.

\section{Practical Contributions}

Despite a widespread belief that the open innovation model is the imperative for creating and profiting from IT, limited practical guidance is available to help managers understand and manage open innovation activities. The findings of this study provide managers with the conceptual clarity of strategic IT alignment, and enable them to select appropriate IT strategies for open innovation strategies, so as to achieve desirable innovation outcomes. First, managers need to be aware of the essential business value of IT in the open innovation context. The basic contention here is that merely investing in building external collaborative relationships and incorporating external knowledge may not necessarily improve organizational innovation performance. It is the implementation of IT within specific open innovation strategies that is more important. For example, managers need to routinely take IT into consideration when formulating and executing open innovation strategies. Recognizing the value of IT as an enabler of open innovation processes, managers may legitimize the role of the $\mathrm{CIO}$ from that of just a technologist, to that of a champion of the implementation of open innovation. 
Second, the results of this study may suggest that managers need to pay attention to designing and deploying different IT strategies for different organizational open innovation strategies. For instance, IT flexibility significantly enhances firms' knowledge sharing and collaboration capability with a wide range of external collaborative partners. For firms intending to draw knowledge from a diverse range of external sources, the IT systems used in open innovation activities (e.g., knowledge management systems, decision support systems, collaborative innovation systems) should be designed so that they can be easily adapted to work with new collaborative partners and easily extended to accommodate new functions. Firms that want to cultivate collaborative innovation opportunities extensively in a small network would find it desirable to access IT systems that provide seamless connections to the innovation collaborators' systems, and which can easily aggregate relevant information from their innovation collaborators' databases. In addition, inter-organizational shared memory systems (shared drives, project rooms, and cloud computing platforms) can be used to support real-time knowledge exchange with innovation collaborators.

Third, given the different impacts of strategic IT alignment on firm innovation outcomes, this research offers important insights that will assist managers in making wise decisions on establishing an IT and open innovation strategy based on the desirable expectations of innovation outcomes. For instance, should a firm aim to introduce more new products, IT integration and external search depth can be included in the organizational open innovation model. If the objective is to explore and introduce products that are new to the firm or to the industry, building flexible IT systems and searching for a wide range of external knowledge sources can be considered by managers.

\section{Conclusion}

Open innovations will remain relevant in an increasingly competitive and fast-paced environment precipitated by new IT developments. New challenges will arise that require a 
deeper understanding of the open innovation implementation in firms. Our study undertook an in-depth, albeit contextual, investigation into how firms employ different open innovation and IT strategies, and their impacts on open innovation outcomes. Based on these analyses, we propose a tentative model of IT and open innovation alignment and highlight the key implications to open innovation and strategic IT alignment literature. Practical implications on how specific organizational IT supporting strategies should be used were also highlighted. Our study is an initial step towards developing an insightful theory into how IT fundamentally enables the deployment and effectiveness of open innovation strategies. 


\section{References}

Ahuja, G. 2000. "The Duality of Collaboration: Inducements and Opportunities in the Formation of Interfirm Linkages," Strategic Management Journal (21:3), pp. 317343.

Ahuja, G., and Morris Lampert, C. 2001. "Entrepreneurship in the Large Corporation: A Longitudinal Study of How Established Firms Create Breakthrough Inventions," Strategic Management Journal (22:6-7), pp. 521-543.

Allen, B.R., and Boynton, A.C. 1991. "Information Architecture: In Search of Efficient Flexiblity," MIS Quarterly (15:4), pp. 435-445.

Amabile, T.M. 1988. "A Model of Creativity and Innovation in Organizations," Research in Organizational Behavior (10), pp. 123-116.

Amabile, T.M. 1996. "Creativity and Innovation in Organizations," Harvard Business School Background Note, pp. 396-239.

Atuahene-Gima, K. 2005. "Resolving the Capability: Rigidity Paradox in New Product Innovation," Journal of Marketing (69:4), pp. 61-83.

Banbury, C. M., \& Mitchell, W. 1995. "The Effect of Introducing Important Incremental Innovations on Market Share and Business Survival," Strategic Management Journal, (16:S1), pp. 161-182.

Barua, A., Konana, P., Whinston, A., and F., Y. 2004. "Assessing Net-Enabled Business Value: An Exploratory Analysis," MIS Quarterly (28:4), pp. 585-620.

Bharadwaj, S., Bharadwaj, A., and Bendoly, E. 2007. "The Performance Effects of Complementarities between Information Systems, Marketing, Manufacturing, and Supply Chain Processes," Information Systems Research (18:4), pp. 437-453.

Boudreau, K.J., and Lakhani, K.R. 2009. "How to Manage Outside Innovation," MIT Sloan Management Review (50:1), pp. 69-76.

Burgelman, R. A. 1994. "Fading Memories: A Process Theory of Strategic Business Exit in Dynamic Environments," Administrative Science Quarterly (39:1), pp. 24-56.

Burt, R. S. 1997. "The Contingent Value of Social Capital," Administrative Science Quarterly (42:2), pp. 339-365.

Brady, T., and Targett, D. 1995. "Strategic Information Systems in the Banking Sector: Holy Grail or Poison Chalice," Technology Analysis \& Strategic Management (7:4), pp. 387-406.

Brislin, R.W. 1970. "Back-Translation for Cross-Cultural Research," Journal of CrossCultural Psychology (1:3), pp. 185-216.

Brown, S. L., \& Eisenhardt, K. M. 1995. "Product Development: Past Research, Present Findings, and Future Directions," Academy of Management Review (20:2), pp. 343378. 
Byrd, T.A., and Turner, D.E. 2000. "Measuring the Flexibility of Information Technology Infrastructure: Exploratory Analysis of a Construct," Journal of Management Information Systems (17:1), pp. 167-208.

Byrd, T.A., and Turner, D.E. 2001. "An Exploratory Examination of the Relationship between Flexible It Infrastructure and Competitive Advantage," Information \& Management (39:1), pp. 41-52.

Chan, Y.E., Huff, S.L., Barclay, D.W., and Copeland, D.G. 1997. "Business Strategic Orientation, Information Systems Strategic Orientation, and Strategic Alignment," Information Systems Research (8:2), pp. 125-150.

Chaney, P. K., \& Devinney, T. M. 1992. "New Product Innovations and Stock Price Performance," Journal of Business Finance \& Accounting (19:5), pp. 677-695.

Chesbrough, and Garman, A.R. 2009. "How Open Innovation Can Help You Cope in Lean Times," Harvard business review (87:12), p. 68.

Chesbrough, Vanhaverbeke, W., and West, J. 2006. Open Innovation: Researching a New Paradigm. Oxford University Press.

Chesbrough, H. 2003. Open Innovation: The New Imperative for Creating and Profiting from Technology. Harvard Business Press.

Chi, L., Ravichandran, T., and Andrevski, G. 2010. "Information Technology, Network Structure, and Competitive Action," Information Systems Research (21:3), pp. 543570.

Christensen, C.M. 2006. "The Ongoing Process of Building a Theory of Disruption," Journal of Product Innovation Management (23:1), pp. 39-55.

Conboy, K., and Morgan, L. 2011. "Beyond the Customer: Opening the Agile Systems Development Process," Information and Software Technology (53:5), pp. 535-542.

Cooper, R.G., and Kleinschmidt, E.J. 1995. "Benchmarking the Firm's Critical Success Factors in New Product Development," Journal of Product Innovation Management (12:5), pp. 374-391.

Croteau, A., and Bergeron, F. 2001. "An Information Technology Trilogy: Business Strategy, Technological Deployment and Organizational Performance," Journal of Strategic Information Systems (10:2), pp. 77-99.

Cui, T., Tong, Y., and Teo, H.H. 2012. "Can Information Technology Bridge Knowledge Distance in Organizational Open Innovation? An Absorptive Capacity Perspective," in: International Conference on Information Systems. Orlando, USA.

Damanpour, F. 1991. "Organizational Innovation: A Meta-analysis of Effects of Determinants and Moderators," Academy of Management Journal (34:3), pp. 555590.

Delery, J.E., and Doty, D.H. 1996. "Modes of Theorizing in Strategic Human Resource Management: Tests of Universalistic, Contingency, and Configurations. Performance Predictions," Academy of Management Journal (39:4), pp. 802-835. 
Di Gangi, P.M., and Wasko, M. 2009. "Steal My Idea! Organizational Adoption of User Innovations from a User Innovation Community: A Case Study of Dell Ideastorm," Decision Support Systems (48:1), pp. 303-312.

Dittrich, K., and Duysters, G. 2007. "Networking as a Means to Strategy Change: The Case of Open Innovation in Mobile Telephony," Journal of Product Innovation Management (24:6), pp. 510-521.

Dodgson, M., Gann, D., and Salter, A. 2006. "The Role of Technology in the Shift Towards Open Innovation: The Case of Procter \& Gamble," $R \& D$ Management (36:3), pp. 333-346.

Duhan, S., Levy, M., and Powell, P. 2001. "Information Systems Strategies in KnowledgeBased Smes: The Role of Core Competencies," European Journal of Information Systems (10:1), pp. 25-40.

Enkel, E., Gassmann, O., and Chesbrough, H. 2009. "Open R\&D and Open Innovation: Exploring the Phenomenon," R\&D Management (39:4), pp. 311-316.

Ettlie, J.E., Bridges, W.P., and O'keefe, R.D. 1984. "Organization Strategy and Structural Differences for Radical Versus Incremental Innovation," Management Science (30:6), pp. 682-695.

Fichman, R.G. 2004. "Going Beyond the Dominant Paradigm for Information Technology Innovation Research: Emerging Concepts and Methods," Journal of Association for Information Systems (5:8), pp. 314-355.

Gefen, D., Rigdon, E.E., and Straub, D.W. 2011. "An Updated and Extensions to SEM Guidelines for Administrative and Social Science Research," MIS Quarterly (35:2), pp. iii-xiv.

Gefen, D., and Straub, D. 2005. "A Practical Guide to Factorial Validity Using PLS-Graph: Tutorial and Annotated Example," Communications of the Association for Information Systems (16:1), p. 109.

Gibson, C.B., and Birkinshaw, J. 2004. "The Antecedents, Consequences, and Mediating Role of Organizational Ambidexterity," Academy of Management Journal (47:2), pp. 209-226.

Gopalakrishnan, R. I., LaPlaca, P. J., and Sharma, A. 2006. "Innovation and New Product Introductions in Emerging Markets: Strategic Recommendations for the Indian Market," Industrial Marketing Management (35:3), pp. 373-382.

Gosain, S., Malhotra, A., and El Sawy, O.A. 2004. "Coordinating for Flexibility in EBusiness Supply Chains," Journal of Management Information Systems (21:3), pp. $7-45$.

Grover, V., and Saeed, K.A. 2007. "The Impact of Product, Market, and Relationship Characteristics on Interorganizational System Integration in Manufacturer-Supplier Dyads," Journal of Management Information Systems (23:4), pp. 185-216.

Hair, H., Lee, J., and Seo, Y. 2006. Multivariate Data Analysis, (6th ed.). New Jersey: Pearson Education. 
Hair, J.F., Ringle, C.M., and Sarstedt, M. 2011. "PLS-Sem: Indeed a Silver Bullet," Journal of Marketing Theory and Practice (19:2), pp. 139-151.

Han, J.K., Kim, N., and Srivastava, R.K. 1998. "Market Orientation and Organizational Performance: Is Innovation a Missing Link?," Journal of Marketing (62:4), pp. 3045.

He, Z.-L., and Wong, P.-K. 2004. "Exploration vs. Exploitation: An Empirical Test of the Ambidexterity Hypothesis," Organization Science (15:4), pp. 481-494.

Henderson, R., and Cockburn, I. 1994. "Measuring Competence? Exploring Firm Effects in Pharmaceutical Research," Strategic Management Journal (15:S1), pp. 63-84.

Hennessey, B.A., and Amabile, T.M. 2010. "Creativity," Annual Review of Psychology (61), pp. 569-598.

Hidding, G.J. 2001. "Sustaining Strategic It Advantage in the Information Age: How Strategy Paradigms Differ by Speed," The Journal of Strategic Information Systems (10:3), pp. 201-222.

Huang, J. W. and Li, Y. H. 2009. "The Mediating Effect of Knowledge Management on Social Interaction and Innovation Performance," International Journal of Manpower (30:3), pp. 285-301.

Huston, L., and Sakkab, N. 2006. "Connect and Develop: Inside Procter \& Gamble's New Model for Innovation," Harvard Business Review (84:3), pp. 58-66.

Im, G., and Rai, A. 2008. "Knowledge Sharing Ambidexterity in Long-Term Interorganizational Relationships," Management Science (54:7), pp. 1281-1296.

Kang, S.C., Morris, S.S., and Snell, S.A. 2007. "Relational Archetypes, Organizational Learning, and Value Creation: Extending the Human Resource Architecture," Academy of Management Review (32:1), pp. 236-256.

Kearns, G.S., and Lederer, A.L. 2003. "A Resource-Based View of Strategic IT Alignment: How Knowledge Sharing Create Competitive Advantage," Decision Science (34:1), pp. 1-29.

Kearns, G.S., and Lederer, A.L. 2004. "The Impact of Industry Contextual Factors on IT Focus and the Use of IT for Competitive Advantage," Information \& Management (41:7), pp. 899-919.

Kumar, R.L. 2004. "A Framework for Assessing the Business Value of Information Technology Infrastructures," Journal of Management Information Systems (21:2), pp. 11-32.

Langdon, C.S. 2006. "Designing Information Systems Capabilities to Create Business Value: A Theoretical Conceptualization of the Role of Flexibility and Integration," Journal of Database Management (17:3), pp. 1-18.

Laursen, K., and Salter, A. 2006. "Open for Innovation: The Role of Openness in Explaining Innovation Performance among U.K. Manufacturing Firms," Strategic Management Journal (27:2), pp. 131-150. 
Leana, C.R., and Van Buren, H.J. 1999. "Organizational Social Capital and Employment Practices," Academy of Management Review (24:3), pp. 538-555.

López-Cabrales, A., Cabello-Medina, C., Carmona-Lavado, A. and Valle-Cabrera, R. 2008. "Managing Functional Diversity, Risk Taking and Incentives for Teams to Achieve Radical Innovations," R\&D Management (38:1), pp. 35-50.

Leiponen, A., and Helfat, C.E. 2010. "Innovation Objectives, Knowledge Sources, and the Benefits of Breadth," Strategic Management Journal (31:2), pp. 224-236.

Levinthal, D., and March, J.G. 1981. "A Model of Adaptive Organizational Search," Journal of Economic Behavior \& Organization (2:4), pp. 307-333.

Melville, N., Kraemer, K., and Gurbaxani, V. 2004. "Review: Information Technology and Organizational Performance: An Integrative Model of It Business Value," MIS Quarterly (28:2), pp. 283-322.

Moore, G.C., and Benbasat, I. 1991. "Development of an Instrument to Measure the Perceptions of Adopting an Information Technology Innovation," Information Systems Research (2:3), pp. 192-222.

Nahapiet, J., and Ghoshal, S. 1998. "Social Capital, Intellectual Capital, and the Organizational Advantage," Academy of Management Review (23:2), pp. 242-266.

Nambisan, S. 2002. "Designing Virtual Customer Environments for New Product Development: Toward a Theory," Academy of Management Review (27:3), pp. 392413.

Nelson, R.R., and Winter, S.G. 1982. An Evolutionary Theory of Economic Change. New York: Harvard University Press.

Oh, W., and Pinsonneault, A. 2007. "On the Assessment of the Strategic Value of Information Technologies: Conceptual and Analytical Approaches," MIS Quarterly (31:2), pp. 239-265.

Ordanini, A., and Parasuraman, A. 2011. "Service Innovation Viewed through a Service Dominant Logic Lens: A Conceptual Framework and Empirical Analysis," Journal of Service Research (14:1), pp. 3-23.

Phillips, L.W., and Bagozzi, R.P. 1986. "On Measuring Organizational Properties of Distribution Channels: Methodological Issues in the Use of Key Informants," Research in Marketing (8:1), pp. 313-369.

Podsakoff, P.M., MacKenzie, S., Lee, J.Y., and Podsakoff, N.P. 2003. "Common Method Biases in Behavioral Research: A Critical Review of the Literature and Recommended Remedies," Journal of Applied Psychology (88:5), pp. 879-903.

Prabhu, J.C., Chandy, R.K., and Ellis, M.E. 2005. "The Impact of Acquisitions on Innovation: Poison Pill, Placebo, or Tonic?," Journal of Marketing (69:1), pp. 114130.

Rai, A., Patnayakuni, R., and Seth, N. 2006. "Firm Performance Impacts of Digitally Enabled Supply Chain Integration Capabilities," MIS Quarterly (30:2), pp. 225-246. 
Rai, A., and Tang, X. 2010. "Leveraging IT Capabilities and Competitive Process Capabilities for the Management of Interorganizational Relationship Portfolios," Information Systems Research (21:3), pp. 516-542.

Ray, G., Muhanna, W.A., and Barney, J.B. 2005. "Information Technology and the Performance of the Customer Service Process: A Resource-Based Analysis," MIS Quarterly (29:4), pp. 625-652.

Reich, B.H., and Benbasat, I. 2000. "Factors That Influence the Social Dimension of Alignment between Business and Information Technology Objectives," MIS Quarterly (24:1), pp. 81-114.

Saraf, N., Langdon, C.S., and Gosain, S. 2007. "Is Application Capabilities and Relational Value in Interfirm Partnerships," Information Systems Research (18:3), pp. 320-339.

Sarker, S., Sarker, S., Sahaym, A., and Bjørn-Andersen, N. 2012. "Exploring Value Cocreation in Relationships between an ERP Vendor and Its Partners: A Revelatory Case Study," MIS Quarterly (36:1), pp. 317-338.

Sawhney, M., Verona, G., and Prandelli, E. 2005. "Collaborating to Create: The Internet as a Platform for Customer Engagement in Product Innovation," Journal of Interactive Marketing (19:4), pp. 4-17.

Soukhoroukova, A., Spann, M., and Skiera, B. 2012. "Sourcing, Filtering, and Evaluating New Product Ideas: An Empirical Exploration of the Performance of Idea Markets," Journal of Product Innovation Management (29:1), pp. 110-112.

Straub, D.W., Boudreau, K.J., and Gefen, D. 2004. "Validating Guidelines for Is Positivist Research," Communications of the Association for Information Systems (13:3), pp. 380-427.

Subramaniam, M. and Youndt, M.A. 2005. "The Influence of Intellectual Capital on the Types of Innovative Capabilities," Academy of Management Journal (48:3), pp. 450463.

Tallon, P.P., and Pinsonneault, A. 2011. "Competing Perspectives on the Link between Strategic Information Technology Alignment and Organizational Agility: Insights from a Mediation Model," MIS Quarterly (35:2), pp. 463-486.

Tiwana, A. 2008. "Do Bridging Ties Complement Strong Ties? An Empirical Examination of Alliance Ambidexterity," Strategic Management Journal (29:3), pp. 251-272.

van de Vrande, V., De Jong, J.P.J., Vanhaverbeke, W., and De Rochemont, M. 2009. "Open Innovation in SMEs: Trends, Motives and Management Challenges," Technovation (29:6-7), pp. 423-437.

Vance, A., Elie-Dit-Cosaque, C., and Straub, D.W. 2008. "Examining Trust in Information Technology Artifacts: The Effects of System Quality and Culture," Journal of Management Information Systems (24:4), pp. 73-100.

Wade, M., and Hulland, J. 2004. "Review: The Resource-Based View and Information Systems Research: Review, Extension, and Suggestions for Future Research," MIS Quarterly (28:1), pp. 107-142. 
Wetzels, M., Odekerken-Schroder, G., and Van Oppen, C. 2009. "Using PLS Path Modeling for Assessing Hierarchical Construct Models: Guidelines and Empirical Illustration," MIS Quarterly (33:1), pp. 177-195.

Whelan, E., Teigland, R., Donnellan, B., and Golden, W. 2010. "How Internet Technologies Impact Information Flows in R\&D: Reconsidering the Technological Gatekeeper," $R \& D$ Management (40:4), pp. 400-413.

Zahra, S.A., and George, G. 2002. "Absorptive Capacity: A Review, Reconceptualization, and Extension," Academy of Management Review (27:2), pp. 185-203.

Zammuto, R.F., Griffith, T.L., Majchrzak, A., Dougherty, D.J., and Faraj, S. 2007. "Information Technology and the Changing Fabric of Organization," Organization Science (18:5), pp. 749-762.

Zhang, Y., and Li, H. 2010. "Innovation Search of New Ventures in a Technology Cluster: The Role of Ties with Service Intermediaries," Strategic Management Journal (31:1), pp. 88-109. 